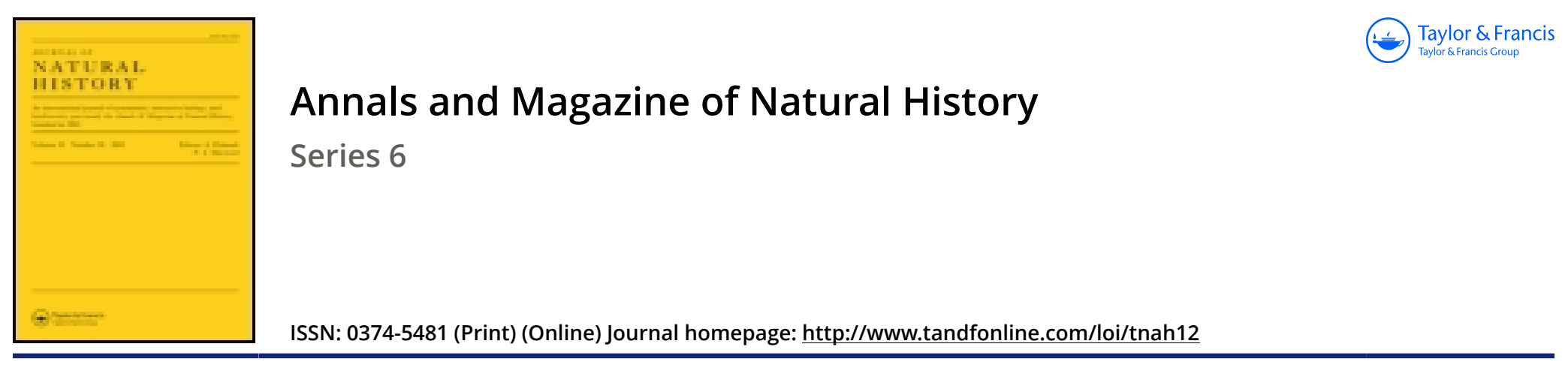

\title{
XLVI.-Note on the early Mesozoic Ganoid, Belonorhynchus, and on the supposed Liassic genus Amblyurus
}

\section{A. Smith Woodward F.G.S. F.Z.S.}

To cite this article: A. Smith Woodward F.G.S. F.Z.S. (1888) XLVI.-Note on the early Mesozoic Ganoid, Belonorhynchus, and on the supposed Liassic genus Amblyurus, Annals and Magazine of Natural History, 1:5, 354-356, DOI: 10.1080/00222938809460743

To link to this article: http://dx.doi.org/10.1080/00222938809460743

曲 Published online: 12 Oct 2009.

Submit your article to this journal $\pi$

Џll Article views: 3

Q View related articles $₫$

47 Citing articles: 1 View citing articles 
XLVI.-Note on the Early Mesozoic Ganoid, Belonorhynchus, and on the supposed Liassic Genus Amblyuras. By A. SMITh Woodward, F.G.S., F.Z.S., of the British Museum (Natural History).

\section{BeLonorhynchus, Bronn.}

Thirty years ago Dr. H. G. Bronn * described a remarkable fossil fish, presumably "Ganoid," from the Upper Trias of Raibl, Carinthia, assigning to it the generic name of Belonorhynchus, in allusion to the length of its Belone-like snont. Eight years later Prof. Rudolph Kner $†$ had the opportunity of examining fifty other well-preserved specimens from the same locality; and the character of the genus and its type species, $B$. striolatus, are thus defined with considerable accuracy and completeness. The head has an enormously produced snout, its total length being nearly equal to that of the whole of the body behind; it is superficially ornamented with transverse rugæ; the lower jaw is as long as the upper; and there are large widely-spaced teeth, with smaller ones intervening. Both pairs of fins are present, comparatively small, and the pelvics are placed far behind; the single dorsal and anal fins are nearly equal in size, opposite, and very remote; and the caudal fin is symmetrical, slightly forked. The body is slender and destitute of ordinary scales, but ridged both dorsally and ventrally by a single series of much elongated, distally pointed, overlapping scutes, which become especially long and needle-shaped upon the tail, beyond the dorsal and anal fins; the lateral line is also supported on each side by a row of broad scutes.

'The head of this fish is so similar to that of Belonostomus that Bronn (loc. cit. p. 12) was originally led to suspect that the Liassic species $B$. acutus and $B$. Anningice, named by Agassiz $\ddagger$ upon the evidence of the head alone, might truly belong to Belonorhynchus. Zittel $\S$ has recently remarked that the first of these certainly does belong to the latter genus, though without publishing the evidence; and I am now able

* H. G. Bronn, "Beiträge zur triasischen Fauna und Flora der bituminösen Schiefer von Raibl," Neues Jahrb. 1858, pp. 7-12, pl, i. figs. 1-10. $\dagger$ R. Kner, " Die Fische der bituminösen Schieter von Raibl in Kärnthen," SB. Akad. Wiss. Wien, math.-naturw. Cl. liii. pt. 1 (18titi), pp. 189-196, pl. vi.

$\ddagger$ L. Agassiz, Rech. Poiss. Foss. vol. ii. pt. 2, pp. 142, 143, pl. xlvii a. figs. 3,4 .

§ K. A. von Zittel, Handb. der Palæont. vol. iii. (1887), p. 222. 
to add that the undescribed $B$. Anningice must also be placed here, this being specifically undistinguishable from $B$. acutus so far as can yet be determined. The fact is of interest, as considerably curtailing the known range of the genus Belonostomus, of which no satisfactory specimens have hitherto been discovered below the lithographic stone of Bavaria and France*.

Conclusive proof of the generic identity of the so-called Belonostomus Anningice with Belonorhynchus is afforded by more than one specimen in the British Museum, but only a single fossil (no. P. 3790) gives much clue to the proportions of its trunk and the characters of some of the scutes. Whereas in the typical $B$. striolatus the head is about equal to the rest of the body in length, in $B$. Anningice it is not more than half as large in proportion; and the snout of the latter is destitute of the superficial transverse striations characteristic of the former. The dorsal scutes, however, upon the middle of the trunk are equally narrow and pointed, and apparently of corresponding form and size.

This discovery will eventually lead to a more complete elucidation of the characters of Belonorhynchus, for the Liassic species being considerably larger than the Triassic and its remains occurring in a more satisfactory matrix it will doubtless throw considerable light upon the structure of the skull when exhaustively studied. At present, however, it must suffice to remark that there appears to be a very close resemblance between the skull and mandible and dentition of this genus and the corresponding parts of Belonostomus; and one tossil lately described $\dagger$ is very suggestive of a large mandibular presymphysial bone, exactly similar to that discovered by Otto Reis $\ddagger$ in the Solenhofen Belonostomus.

The Liassic specimens and a few additional examples of B. striolatus from Raibl also seem to determine definitely

- Agassiz (tom. cit. pt. 2, p. 143) named a species from the Stonesfield Slate B. leptosteus, and Phillips (Geol. Oxford, 1871, p. 180, diagr. xl. fig. 4) figured under this namə a portion of mandible which might pertain either to Belonostomus or Belonorhynchus. The evidence is very uncertain, and some of the supposed fragments of Belonostomus from Stonesfield, so labelled in collections, doubtless belong to a species of Aspidorhynchus, of which Phillips figured a mandibular ramus under the name of "Pholidophorus minor 1, Agass." (op. cit. p. 180, diagr. xl. figs. 5, 6), and of which there are satisfactory specimens in the British Museum.

+ Smith Wood ward, "On the Mandible of Belonostonus cinctus, \&c.," Quart. Journ, Gen]. Soc. vol, xliv. (188૪), p. 147, pl. vii. fig. 14.

$\ddagger$ O. Reis, "Ueber Belonustomus, Aspidorhynchus, und ihre Beziehungen zum lebonden Lepidosters," SB. math.phys. Cl. bay. Akad. Wiss. 1887, p. 169 , pl. i. fig. 4. 
that in Belonorhynchus the notochord was persistent. Kner* suspected that there were complete vertebral centra in the anterior portion of the trunk and small triangular calcifications in the sheath of the notochord more posteriorly; but the small bodies must doubtless be regarded as the expanded proximal portions of the neural and hrmal arches, quite similar to those of many other early Ganoids. It may be added, moreover, that Bronn's description of the fin-rays as transversely jointed is correct, though subsequently questioned by Kner, the fossils being often deceptive owing to the circumstances of preservation.

With regard to the systematic position of the genus, Kner institutes many comparisons with the living Fistularia, and Lütken $\dagger$ has suggested that it is probably related to the Cretaceous Dercetis. The characters of the skull, however, together with the disposition of the fins and the primitive nature of the vertebral axis, appear to indicate much more aftinity with Belonostomus and its allies, as originally recognized by Bronn; and the genus may therefore be referred to a nearly related family, the Belonorlyynchida, characterized as follows:-Body long and slender; snout much elongated and pointed. Notochord persistent, the bases of the arches expranded. Paired fins moderately developed; dorsal and anal fins large, nearly equal and opposite, very remote; caudal symmetrical ; fulcra minute or absent. No continuous squamation, but a median longitudinal series of dorsal and ventral scutes, and a single lateral series on each side supporting the lateral line.

\section{Amblyurus, Agassiz.}

While referring to Liassic Ganoids it may be well to place on record a correction which was made some years ago by Mr. William Davies in the British Museum, but does not appear to have been hitherto published. Whatever be the nature of the head-fragment associated by Agassiz with the genus Amblyurus, there can be no doubt that the type specimens of the single species, Amblyurus macrostomus t, are really vertically crusled specimens of Dapedius; and the name thus falls into the synonymy of this well-known Lower Liassic fish.

* R. Kner, loc. cit. p. 192, pl. vi. tigs. l, c.

$\dagger$ C. F. Lütken, "Professur Kner"s Classitication of the Ganoids," Geol. Misg. vol, v. (18(88), p. 432.

f L. $\Delta$ gassiz, tom. cit. pt. 1, p. 220, pl. xxve. 